Рощик I. А. [1; ORCID ID: 0000-0002-3155-2727], к.е.н., доцент,

Овсійчук О. С. ${ }^{[1 ; 0 R C I D ~ I D: ~ 0000-0001-7925-8378], ~}$ здобувач вищої освіти першого (бакалаврського) рівня

${ }^{1}$ Національний університет водного господарства та природокористування, м. Рівне

\title{
РИНОК ІТ-ПРОДУКТІВ: АНАЛІТИКА ДЛЯ ЗАСНУВАННЯ I РОЗВИТКУ БІЗНЕСУ
}

Обґрунтовано теоретико-методичні засади аналізу ринку ITпродуктів для прийняття рішень про заснування та розвиток бізнесу. Уточнено місце IT-продуктів та IT-сфери у статистичних класифікаціях. За запропонованою в роботі методикою оцінено місткість ринку IT-продуктів за період 2010-2018 років в Україні та проаналізовано його розвиток 3 використанням статистичних методів аналізу рядів динаміки. На основі кореляційно-регресійного аналізу складено модель залежності місткості ринку IT-продуктів від ВВП на душу населення України, яка може бути використана для прогнозування. Виявлено основні галузеві характеристики покупців IT-продуктів та оцінено резерви нарощення споживання і обсягів ринку. Визначено основні характеристики виробників IT-продуктів. За запропонованим в роботі показником вартості робочого місця оцінено інвестиційні потреби в IT-сфері. 3 використанням співвідношення продуктивності праці і вартості робочого місця, рентабельності операційної діяльності проаналізовано ефективність IT-підприємництва в Україні.

Ключові слова: інформаційні технології; ринок ІТ-продуктів; місткість ринку; прогнозування; вартість робочого місця.

Постановка проблеми. Ринок ІТ-продуктів - найдинамічніший ринок не тільки в Україні, а й у всьому світі. Щоб зайняти і зберегти бажану нішу на цьому ринку, потрібно приймати управлінські рішення, що ґрунтуються на актуальній і повній інформації про його розвиток. Крім окремих маркетингових досліджень, корисною в цьому контексті може бути інформація, отримана Держстатом із статистичних спостережень. Разом з тим, з метою обґрунтування доцільності створення або трансформування бізнесу в сфері IT, офіційна інформація не завжди є прийнятною та потребує додаткової обробки, побудови специфічних аналітичних показників та використання специфічних методів аналізу. Однак, на даний час немає вичерпних досліджень, присвячених цій проблемі. 
Аналіз останніх досліджень. Дослідженнями тенденцій розвитку ринку інформаційних технологій займалися такі вітчизняні вчені, як О. С. Бабанін [1], Р. О. Винничук [2], Л. М. Ганущак-Єфіменко [3], О. В. Журавльов [4], С. Е. Сардак [4] та інші. Зокрема, Бабанін О. С. розглядає проблематику розвитку IT-індустрії в Україні через призму світових тенденцій розвитку галузі. Винничук Р. О. досліджує український ринок IT, встановлюючи основні проблеми та перешкоди для інформатизації українського суспільства, а також світової інтеграції галузі. Сардак С. Е., визначаючи глобальні тенденції розвитку світового IТ-ринку, ідентифікує потенційні загрози і виклики. Значної уваги заслуговують дослідження Л. М. ГанущакЄфіменко, в якому розкрито особливості розвитку підприємництва ITіндустрії в умовах євроінтеграції, а також Журавльова О. В., в якому на підставі статистичного дослідження визначено проблеми ринку інформаційних технологій та запропоновано способи їх вирішення.

Однак, методичні засади аналізу ринку ІТ-продуктів для прийняття рішень про заснування та розвитку бізнесу залишаються все-таки не достатньо висвітленими у спеціалізованій літературі та актуальні й донині.

Мета і завдання дослідження - обґрунтування теоретикометодичних засад аналізу ринку IT-продуктів для прийняття рішень про заснування та розвиток бізнесу.

Виклад основного матеріалу. Передумовою якісного статистичного аналізу ринку IT-продуктів має бути чітка визначеність IT-продукту як виду продукції та IT-сфери як виду діяльності в статистичних класифікаціях. Оскільки це питання залишається не вирішеним, то, 3 метою нашого дослідження, пропонуємо врахувати думку експертів із ІТ-сфери [6], [7], Основну номенклатуру продукції [8], Класифікацію зовнішньоекономічних послуг [9] і визначити IT-продукти як такі, що виробляються частиною суб'єктів господарювання секції J «Послуги у сферах інформації та телекомунікацій» (табл. 1), а також як «Комп'ютерні послуги» з метою експорту (імпорту). 
Таблиця 1

Види економічної діяльності за КВЕД-2010, які виробляють IT-продукти' [10]

\begin{tabular}{|l|l|}
\hline Код & \multicolumn{1}{|c|}{ Назва } \\
\hline 58.2 & Послуги з видання програмного забезпечення \\
\hline 58.21 & Послуги з видання комп'ютерних ігор \\
\hline 58.29 & Послуги з видання іншого програмного забезпечення \\
\hline $\mathbf{6 2}$ & $\begin{array}{l}\text { Послуги з комп'ютерного програмування, консультування } \\
\text { та послуги супутні }\end{array}$ \\
\hline 62.01 & Послуги з комп'ютерного програмування \\
\hline 62.02 & Послуги консультаційні з питань інформатизації \\
\hline 62.03 & Послуги з керування комп'ютерним устаткуванням \\
\hline 62.09 & $\begin{array}{l}\text { Послуги у сфері інші інформаційних технологій і } \\
\text { комп'ютерних систем }\end{array}$ \\
\hline $\mathbf{6 3 . 1 1}$ & $\begin{array}{l}\text { Послуги з оброблення даних, розміщення інформації на } \\
\text { вебвузлах і послуги супутні }\end{array}$ \\
\hline $\mathbf{6 3 . 1 2}$ & Інформаційне наповнення вебпорталів \\
\hline
\end{tabular}

Інформацію для прийняття рішення про заснування або трансформацію бізнесу в IT-сфері в даному дослідженні розглянемо за такими напрямами:

- місткість ринку IT-продуктів та його прогнозні значення;

- основні характеристики споживачів IT-продуктів;

- конкурентна ситуація в IT-сфері;

- доходи, витрати, ефективність та фінансові результати суб'єктів господарювання в ІТ-сфері.

Місткість українського ринку IT-продуктів (реальну) пропонується визначати як різницю обсягу реалізованої ІТ-продукції і чистого експорту комп'ютерних послуг, що в свою чергу $є$ різницею між їх експортом та імпортом. За офіційними статистичними даними ринок IT-продуктів в Україні у 2019 році становив 172 млрд грн і зріс порівняно з 2010 роком на 160 млрд грн. або в 14,33 рази (табл. 2). Таке зростання відбулося внаслідок зростання обсягів реалізації ITпродуктів вітчизняного виробництва вітчизняним споживачам в 15 разів, збільшення експорту комп'ютерних послуг в 26 рази, а імпорту - в 8 разів. Українські споживачі у 2019 році в основному купували ІТ-продукти вітчизняного виробництва (95,34\%), тоді як імпорт комп'ютерних послуг становив 4,66\%. За аналізований період конкурентоспроможність IT-продуктів вітчизняного виробництва

\footnotetext{
1 зазначені коди використовуються в усьому графічному матеріалі роботи
} 
посилилась, оскільки в загальних обсягах українського ринку їх частка збільшилась на 4,77 в.п.

В структурі обсягів реалізації вітчизняних ІТ-продуктів (включаючи експорт) у 2019 році переважали «послуги 3 комп'ютерного програмування»-64,25\% (рис. 1).

Таблиця 2

Визначення місткості ринку ІТ-продуктів в Україні у 2010-2019 рр., млрд грн (складено авторами за [11; 12])

\begin{tabular}{|c|c|c|c|c|c|c|c|c|c|c|c|c|}
\hline Назва показника & 음 & 官 & & $\frac{m}{\delta}$ & さ & 兄 & $\stackrel{\circ}{\stackrel{0}{N}}$ & 동 & $\stackrel{\infty}{\infty}$ & $\frac{a}{\circ}$ & $\begin{array}{c}\text { Базис- } \\
\text { ний } \\
\text { абсо- } \\
\text { лютний } \\
\text { приріст }\end{array}$ & $\begin{array}{l}\text { Базис- } \\
\text { ний темп } \\
\text { зростан- } \\
\text { ня, разів }\end{array}$ \\
\hline $\begin{array}{l}\text { Обсяг реалізованоі } \\
\text { IT-продукції }\end{array}$ & 13 & 17 & 25 & 31 & 43 & 75 & 101 & 131 & 175 & 217 & 204 & 16,69 \\
\hline $\begin{array}{l}\text { Експорт } \\
\text { комп'ютерних послуг }\end{array}$ & 2 & 3 & 5 & 7 & 13 & 22 & 29 & 35 & 44 & 53 & 51 & 26,50 \\
\hline $\begin{array}{l}\text { Обсяг реалізованоі } \\
\text { IT-продукції } \\
\text { мінусом експорту } \\
\text { комп'ютерних послуг }\end{array}$ & 11 & 14 & 20 & 24 & 30 & 53 & 72 & 96 & 130 & 164 & 153 & 14,91 \\
\hline $\begin{array}{l}\text { Імпорт комп'ютерних } \\
\text { послуг }\end{array}$ & 1 & 1 & 2 & 2 & 3 & 4 & 5 & 5 & 7 & 8 & 7 & 8,00 \\
\hline $\begin{array}{l}\text { Місткість ринку IT- } \\
\text { продукції }\end{array}$ & 12 & 16 & 22 & 26 & 33 & 57 & 77 & 102 & 137 & 172 & 160 & 14,33 \\
\hline
\end{tabular}

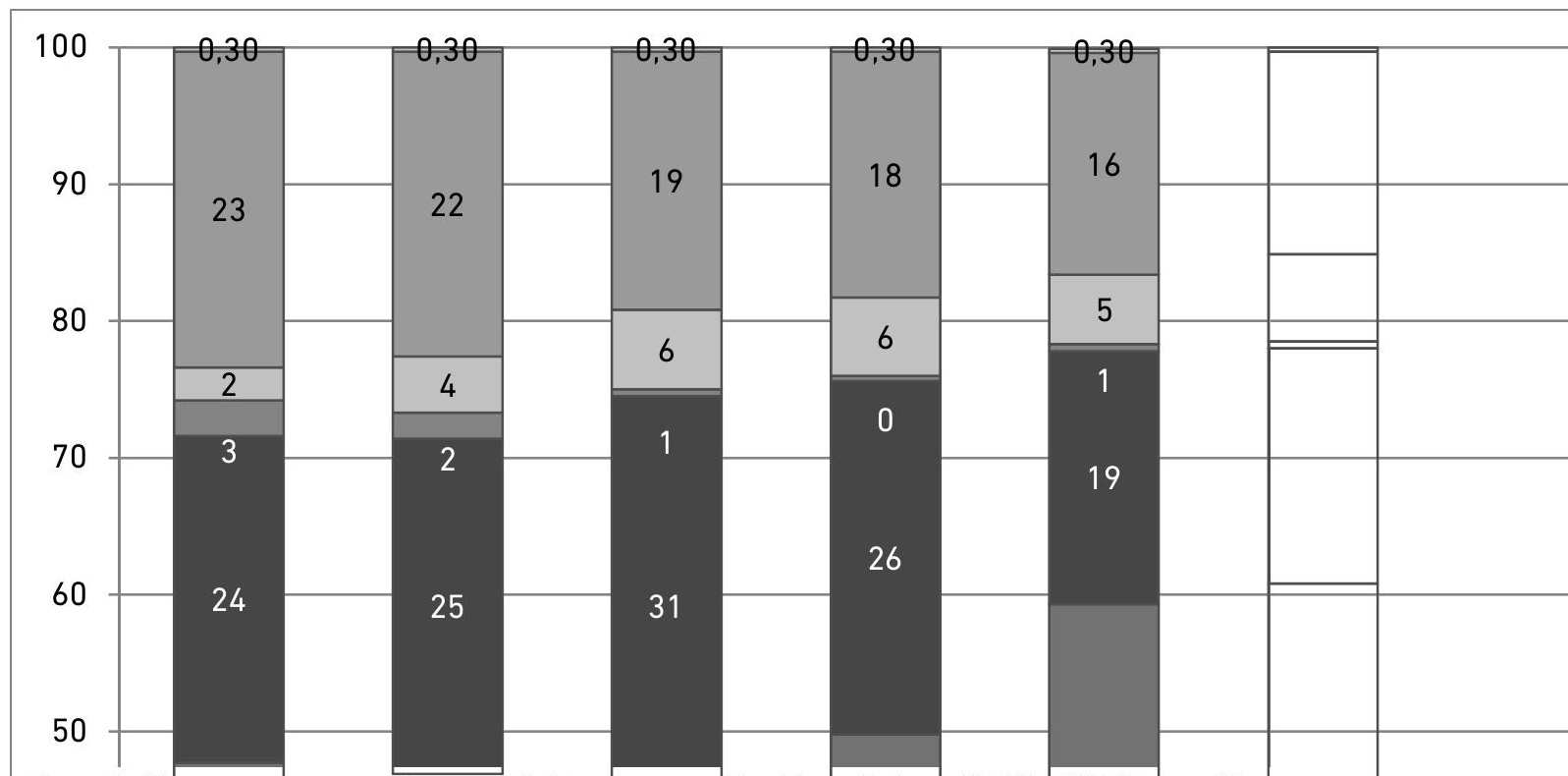

Рис. 1. С руктура реалізованої ІТ-продукції в Україні за 2010-2019 рр., \% (складено авторами за [1 1]) 
Їх частка збільшилась за аналізований період на 31,95 в.п. Водночас незначною у 2019 році в загальних обсягах реалізації була частка «послуг з видання програмного забезпечення» $(2,24 \%)$, яка зменшилась із $15,40 \%$ у 2010 році, що свідчить про загострення в Україні проблем із захистом авторського права та патентуванням комп'ютерних програм.

Для прогнозування місткості ринку IT-продуктів застосуємо метод екстраполяції, склавши в результаті кореляційно-регресійного аналізу економетричну модель залежності місткості ринку ITпродуктів від ВВП на душу населення України за даними 20102019 рр. (табл. 3), здійсненого в Excel пакет «Аналіз даних»:

Таблиця 3

Вихідні дані для прогнозування місткості ринку IT-продуктів в Україні (складено авторами за $[11 ; 12 ; 13]$ )

\begin{tabular}{|l|l|l|l|l|l|l|l|l|l|l|}
\hline Назва показника & 2010 & 2011 & 2012 & 2013 & 2014 & 2015 & 2016 & 2017 & 2018 & 2019 \\
\hline $\begin{array}{l}\text { Місткість ринку } \\
\text { IТ-продукції, } \\
\text { Млн грн }\end{array}$ & 10656 & 14365 & 20083 & 23935 & 30306 & 52945 & 71730 & 96388 & 130235 & 172241 \\
\hline $\begin{array}{l}\text { Валовий } \\
\text { внутрішній } \\
\begin{array}{l}\text { продукт України у } \\
\text { розрахунку на } \\
\text { одну особу, грн }\end{array}\end{array}$ & 24798 & 29980 & 32480 & 33965 & 36904 & 46413 & 55899 & 70233 & 84235 & 94661 \\
\hline
\end{tabular}

1) економетрична модель залежності місткості ринку ITпродуктів має вигляд у=2,237x-51713,870, є статистично значимою, оскільки розрахункове значення критерію Фішера $(663,689)$ більше за критичне $(5,318)$;

2) коефіцієнт регресії $b_{1}=2,237$ означає, що із збільшенням ВВП на душу населення на 1 грн місткість IT-ринку збільшиться в середньому на 2,237 млн грн; коефіцієнт є статистично значимим, оскільки розрахункове значення критерію Стьюдента $(25,762)$ більше за критичне $(2,306)$;

3) місткість ринку IT-продуктів на 98,8\% пояснюється впливом обсягів ВВП на душу населення, і лише на 0,4\% - впливом інших факторів, не врахованих в моделі, оскільки коефіцієнт детермінації $\mathrm{R}^{2}=0,988$;

4) залежність місткості ринку IT-продуктів від обсягів ВВП на душу населення в Україні $є$ тісною і прямою, оскільки коефіцієнт парної кореляції $r_{x y}=0,994-$ із збільшенням ВВП на душу населення місткість IT-ринку збільшується; коефіцієнт парної кореляції $\epsilon$ статистично значимим, оскільки розрахункове значення критерію Стьюдента $(25,762)$ більше за критичне $(2,306)$; 
5) з ймовірністю 0,95 можна прогнозувати, що при зменшенні ВВП на душу населення у 2020 році орієнтовно на 5000 грн (5\%), ITринок буде знаходитись в межах від 120 до 178 млрд грн або дорівнюватиме 149 млрд грн в середньому.

Застосування складеної моделі для прогнозування узгоджується з думкою багатьох експертів, які вважають, що обсяги споживання IT-продуктів стримуються обсягами економіки в цілому [6]. Діапазон прогнозних значень підтверджується також даними звіту IT-асоціації в Україні про вплив коронакризи 2020 року на ITбізнес: збільшилася кількість IT-компаній, кількість IT-працівників, обсяги доходів IT-компаній, але при цьому значна частина компаній мали затримки з оплатою за надані IT-послуги або продукти від клієнтів, частина компаній мали проблеми із залученням нових клієнтів [14].

Основними покупцями програмного забезпечення у 2019 році за офіційними статистичними даними є підприємства секторів J «Інформація та телекомунікація» $(37 \%$ від усіх 5,9 млрд грн капітальних інвестицій на цю мету), $\mathrm{G}$ «Оптова і роздрібна торгівля, ремонт автотранспортних засобів і мотоциклів» (14,7\%) і C «Переробна промисловість» $(11,0 \%)$ - рис. 2. Накопиченим підсумком за аналізований період з 2010 по 2019 роки найбільше інвестицій у програмне забезпечення було здійснено в секторах J (40,1\% від усіх 33,8 млрд грн), G $(16,8 \%)$ і C $(11,3 \%)$.

За інформацією Держстату також можна встановити галузеву приналежність компаній, що найчастіше мають свій сайт, купують послуги хмарних обчислень, замовляють аналіз «великих даних». У 2019 році це також переважно підприємства секції G (26,28\%; $27,64 \% ; \quad 25,89 \%$ відповідно), C $(30,01 \% ; 23,74 \% ; 21,89 \%)$ i F «Будівництво» (7,82\%; 9,89\%; 9,90\%) [16]. Для встановлення резервів потенційного розширення попиту на ці IT-продукти можна врахувати дані Держстату про частку підприємств галузі, які вже їх споживають: свій сайт у 2019 році мали найрідше транспортні підприємства (22,1\%); послуги хмарних обчислень замовляли найрідше підприємства із секції $L$ «Операції із нерухомим майном» $(6,7 \%) ;$ аналіз «великих даних» найрідше купували будівельні підприємства (3,5\%) [16].

Така галузева структура капітальних інвестицій зумовлена відповідною галузевою структурою наявних ресурсів для їх освоєння. Зокрема, за даними обстежень Держстату найбільша частка підприємств у 2019 році, що використовують комп'ютери (25\%), найбільша частка комп'ютеризованих робочих місць (27\%), 
найбільша частка підключених до Інтернету підприємств (25\%), найбільша частка підприємств з ІКТ-фахівцями (25\%)

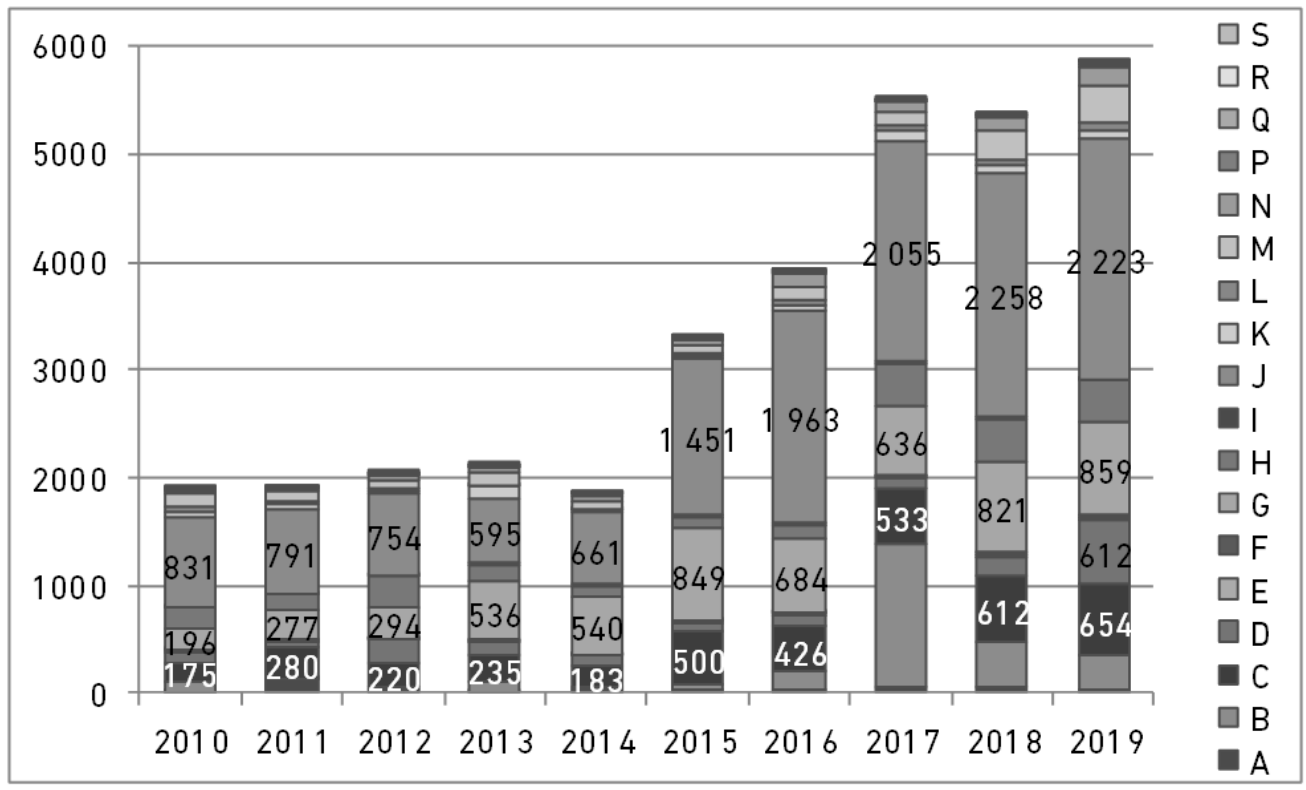

Рис. 2. Обсяги капітальних інвестицій підприємств в програмне забезпечення в Україні за 2010-2019 рр. за видами економічної діяльності, млн грн: А-S - секції відповідно до КВЕД-2010

(складено авторами за [10; 15])

знаходиться в переробній промисловості [16]. За статистикою, найбільші резерви використовувати комп'ютери має секція $\mathrm{N}$ «Діяльність у сфері адміністративного та допоміжного обслуговування» (19,8\% підприємств галузі); найбільше некомп'ютеризованих робочих місць у секції Е «Водопостачання; каналізація, поводження 3 відходами» (79,3\%); найбільше непідключених до інтернету підприємств у секції I «Тимчасове розміщування й організація харчування» (22,8\%) [16].

Населення - теж важливий покупець ІТ-продуктів, оскільки за 2010-2018 роки майже в 1,5 рази зросла його забезпеченість персональними комп'ютерами, в 1,2 рази - мобільними телефонами, майже в 6 разів - ноутбуками та у 19 разів - планшетами [17]. Однак, ще не кожне домогосподарство має хоча б 1 комп'ютер, ноутбук або планшет - разом забезпеченість становить 91 прилад у розрахунку на 100 домогосподарств [17]. Попри зростання рівня користування Інтернетом (у 2018 році до 62,6\% населення), лише 75,1\% з них робить це не менше ніж раз на день [18]. Незважаючи на зростання 
рівня цифрових вмінь, майже 15,1\% населення взагалі їх не мають [19].

Конкуренція в IT-сфері за аналізований період суттєво посилилась, оскільки кількість суб'єктів господарювання, що виготовляють IT-продукцію, з 2010 до 2019 року збільшилась на 146 тис. одиниць або в 5,19 раза, зокрема за рахунок збільшення в 5,73 раза кількості фізичних осіб-підприємців, які мають можливість вести бізнес на спрощеній системі оподаткування, в 1,76 раза мікропідприємств і тільки в 1,52 раза - великих, середніх, малих підприємств (рис. 3).

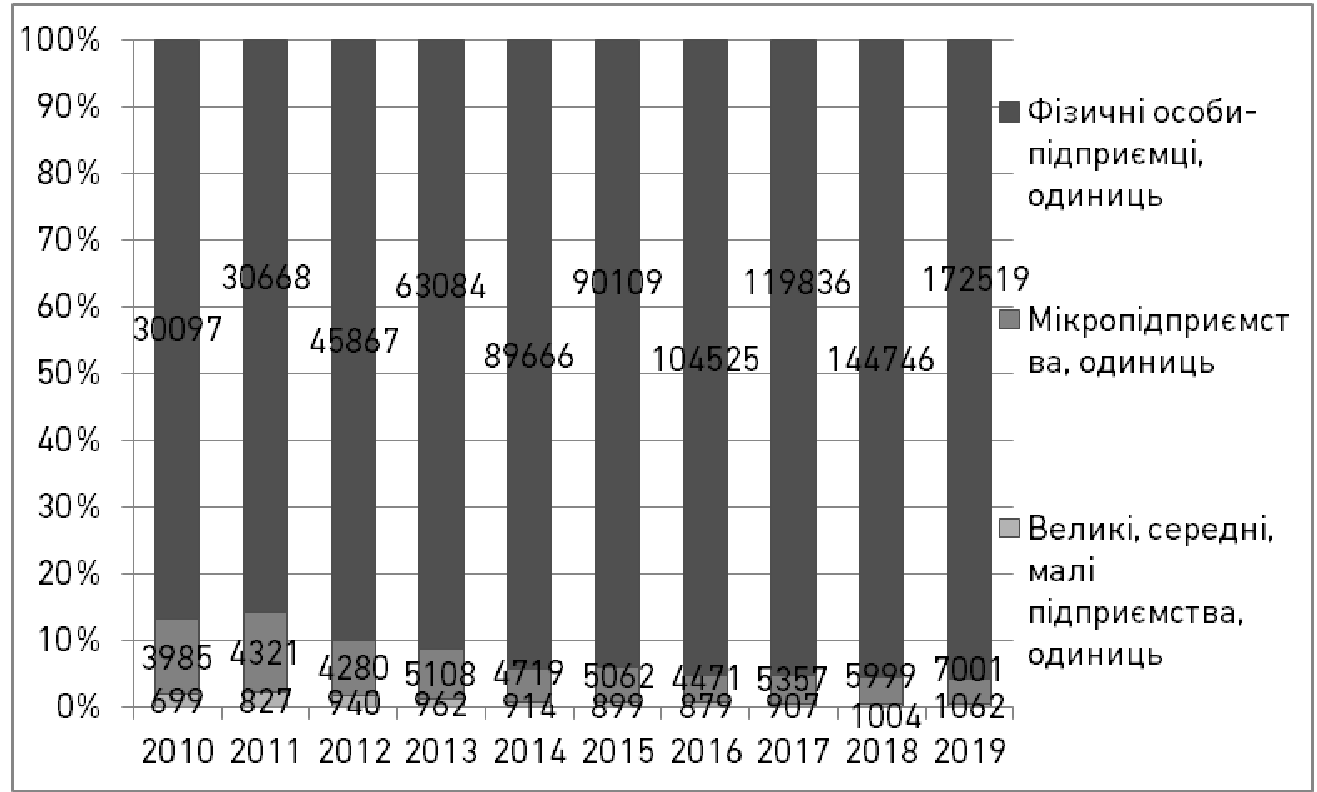

Рис. 3. Кількість і структура суб'єктів господарювання, які виготовляють ITпродукцію в Україні, за 2010-2019рр. (складено авторами за [20; 21])

Кількість зайнятих в IT-секторі збільшилась в 3,34 рази, зокрема, у фізичних осіб-підприємців - в 5,40 рази, до понад 238 тис. осіб або 2,60\% від загальної кількості зайнятих в Україні (рис.4). Середнє IT-підприємство мало у 2019 році 7,21 зайнятих працівників, тоді як фізична особа-підприємець - тільки 1,04 (тобто в основному це лише сам підприємець). Більшість підприємців перебувала на 3 або 2 групі оподаткування: можуть як мати (до 10 осіб - II група), так i не мати найманих працівників; можуть мати річний дохід у 2021 році не більше 1167 або 834 мінімальних заробітних плат відповідно; сплачують єдиний податок $5 \%$ від доходу як неплатники ПДВ або 20\% від мінімальної зарплати [22]. 


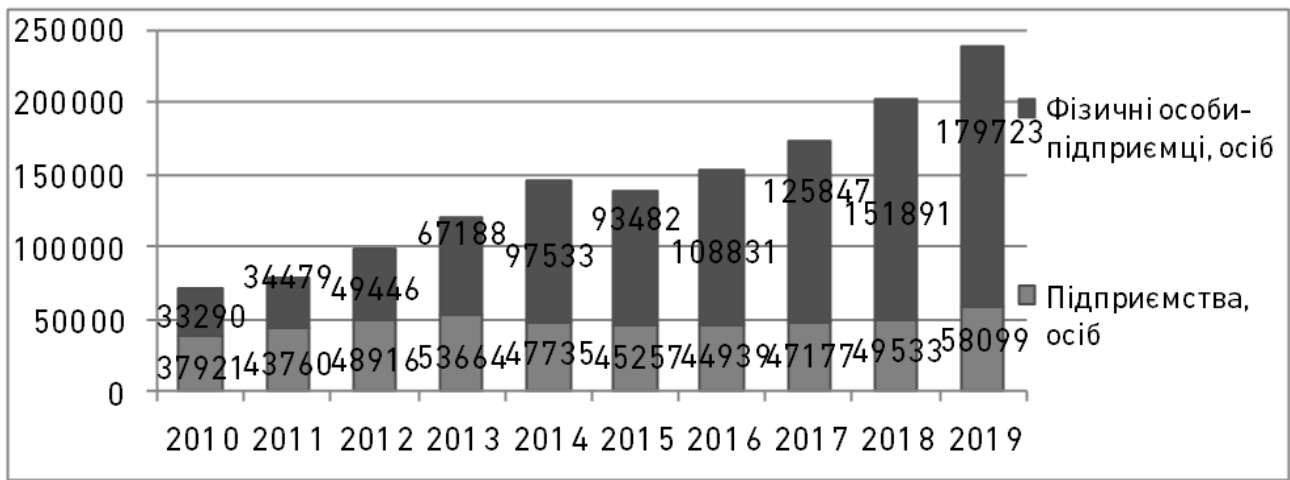

Рис. 4. Кількість зайнятих працівників у суб'єктів господарювання, які виготовляють IT-продукцію в Україні, за формами реєстрації за 2010-2019 рр. (складено авторами за [23])

Для оцінювання інвестиційних потреб в IT пропонуємо використати показник вартості робочого місця - співвідношення сальдо балансу та кількості зайнятих. Для оцінювання здатності ITбізнесу покривати витрати пропонуємо порівнювати вартість робочого місця із продуктивністю праці (співвідношенням обсягу реалізованої продукції та кількості зайнятих). Так, відповідно до офіційних даних IT-підприємств середнє робоче місце в IT у 2019 році вартувало 823 тис. грн, і приносило 1621 тис. грн доходу - рис. 5.

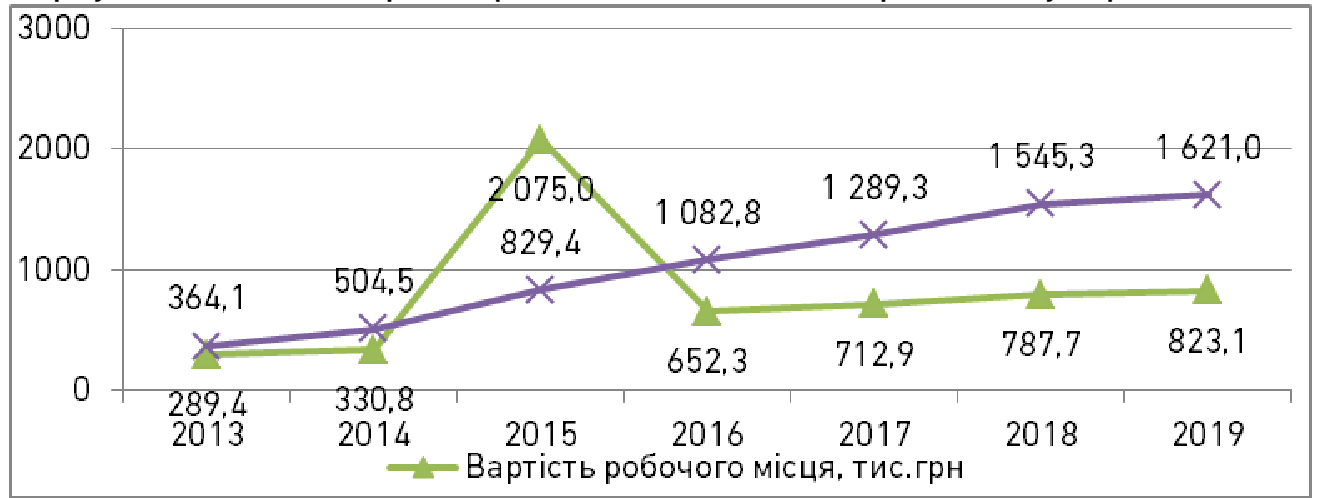

Рис. 5. Вартість та продуктивність робочого місця на підприємствах ITсфери за 2013-2019 роки (розраховано авторами за [11; 23; 24])

Співвідношення продуктивності та вартості робочого місця в IT щороку зростає - з 1,258 раза у 2013 році до 1,97 раза у 2019, що свідчить про зростання швидкості окупності інвестицій. Для галузі вона вища (1,97 раза) ніж для середнього підприємства в економіці України $(0,851$ раза). 


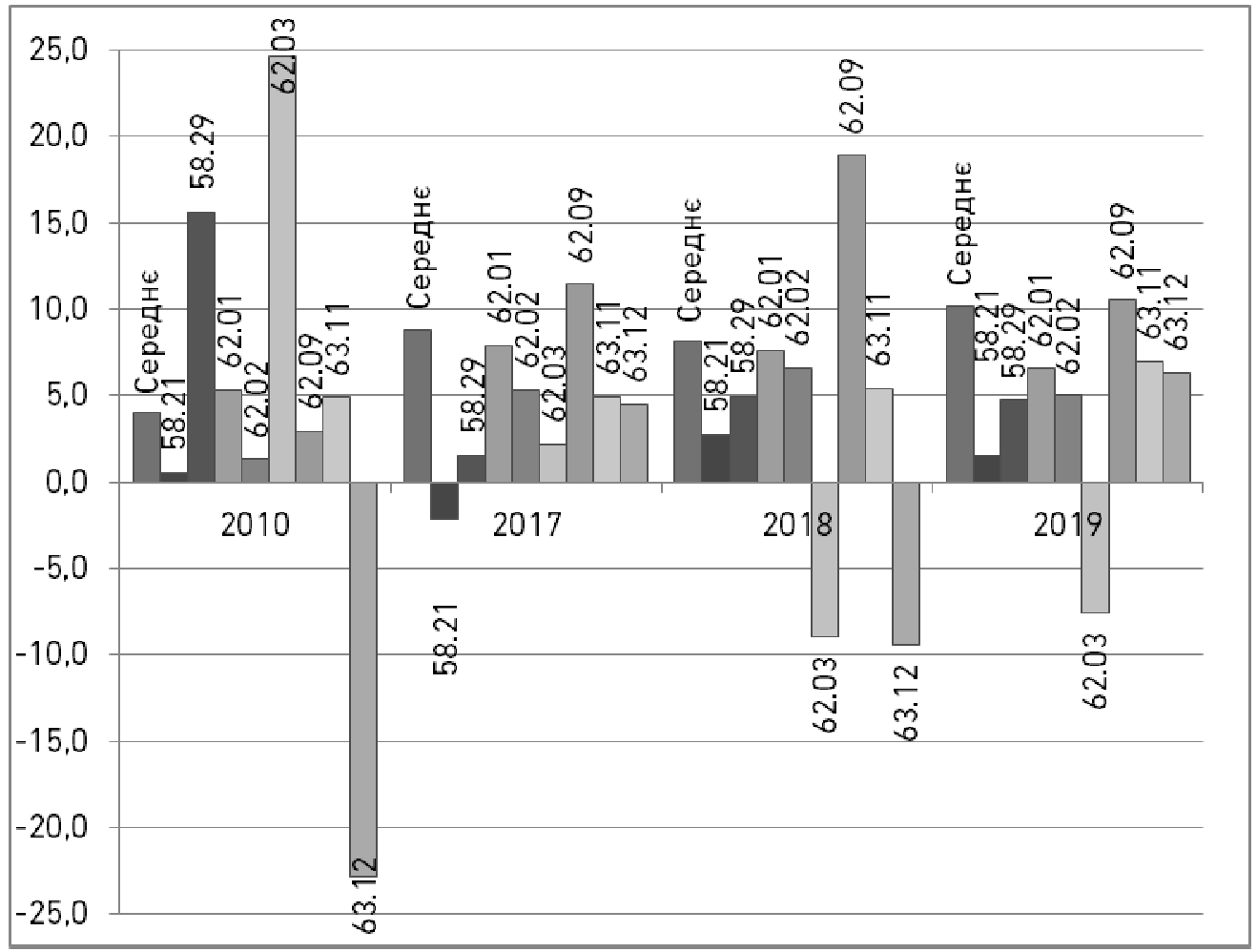

Рис. 6. Рівень рентабельності (збитковості) операційної діяльності ІТ-підприємств за видами економічної діяльності та середній рівень в економіці України за 2010-2019 рр., \% (складено авторами за [25])

Загалом виготовлення IT-продукції в Україні $€$ рентабельним бізнесом (рис. 6). У 2019 році рівень рентабельності у сфері інших інформаційних технологій і комп'ютерних систем (10,5\%) навіть перевищив середню рентабельність в Україні (10,2\%), стабільно демонструючи додатну рентабельність протягом аналізованих 10 років. Прибутковим стало інформаційне наповнення вебпорталів (6,34\%), рентабельність чого була від'ємною протягом 7 із 10 аналізованих років. Однак за офіційними статистичними даними збитки отримали суб'єкти господарювання 3 керування комп'ютерним устаткуванням, що свідчить зменшення потреби у клієнтів здійснювати аутсорсинг цього виду робіт.

Висновки. Здійснений за запропонованою методикою аналіз ринку ІТ-продуктів в Україні свідчить, що ринок швидко розвивається і ще не досяг свого потенційного максимуму, але залежить від величини та темпів розвитку економіки; основними покупцями IT-продукції $\epsilon$ IKT, торгівля та переробна промисловість; основними виробниками IT-продукції є фізичні особи-підприємці; 
кожне робоче місце в IT приносить майже вдвічі більше доходу, ніж вартує; рентабельність бізнесу знаходиться на рівні середньогалузевої рентабельності.

1.Бабанін О.С. Статистика розвитку IT-ринку в США, Україні й світі. Статистика України. 2013. № 1. С. 22-27. URL: http://nbuv.gov.ua/j-pdf/su_2013_1_6.pdf. 2. Винничук Р. О., Склярук Т. В. Особливості розвитку IT-ринку в Україні: стан та тенденції. Вісник Національного університету «Львівська політехніка». Логістика. 2015. № 833. C. 3-8. URL: http://nbuv.gov.ua/UJRN/VNULPL_2015_833_3 (дата звернення: 08.12.2020). 3. Ганущак-Єфіменко Л. М. Особливості розвитку підприємництва в IT-сфері України. Актуальні проблеми економіки. 2016. № 10. C. 55-67. URL: http://nbuv.gov.ua/UJRN/ape_2016_10_8 (дата звернення: 08.12.2020). 4. Журавльов О. В., Сімачов О.А. Статистичне дослідження ринку ITпослуг в Україні. Статистика України. 2018. № 4. С. 25-33. URL: https://sujournal.com.ua/index.php/journal/article/view/207/183 (дата звернення: 08.12.2020). 5. Сардак С. Е., Ставицька А. В. Дослідження структури і тенденцій розвитку світового ринку інформаційних технологій. Технологический аудит и

резервы производства. № 4/5(24). 2015. C. 96-100. URL:
http://nbuv.gov.ua/UJRN/Tatrv_2015_4\%285\%29_21 (дата звернення: 08.12.2020). 6. Розвиток української IT-індустрії. Аналітичний звіт. Київ, жовтень 2018. 68 с. URL: https://ko.com.ua/files/u125/ukrainian_it_industry_report_ukr.pdf (дата звернення: 08.12.2020). 7. Волянюк І. Особливості бухобліку в ІТ-компаніях. Вісник. Офіційно про податки. №12 (916) від 24.03.2017 p. URL: http://www.visnuk.com.ua/uk/publication/100004441-osoblivosti-bukhobliku-v-itkompaniyakh?issue=5583 (дата звернення: 08.12.2020). 8. Основна номенклатура продукції (ОНП). URL: http://www.ukrstat.gov.ua/klasf/st_kls/onp_2020.pdf (дата звернення: 16.03.2020). 9.Класифікація зовнішньоекономічних послуг. URL: http://www.ukrstat.gov.ua/klasf/st_kls/kzep_xls.rar (дата звернення: 08.12.2020). 10. Класифікація видів економічної діяльності (КBEД-2010). URL: http://www.ukrstat.gov.ua/klasf/nac_kls/dc_009_xls.rar. (дата звернення: 08.12.2020). 11. Обсяг реалізованої продукції (товарів, послуг) суб'єктів господарювання за видами економічної діяльності (2010-2019). URL: http://www.ukrstat.gov.ua/operativ/operativ2018/fin/pssg/pssg_u/orpsg_ek_2010_2 019_ue.xlsx. (дата звернення: 08.12.2020). 12. Динаміка зовнішньої торгівлі послугами за видами (2008-2019). URL: http://www.ukrstat.gov.ua/operativ/operativ2008/zd/dseip/ dseip2007_u.xls. (дата звернення: 08.12.2020). 13. Валовий внутрішній продукт (1990-2019). URL: http://www.ukrstat.gov.ua/operativ/operativ2020/vvp/vvp_rik/vvp_rik90-19.xlsx. (дата звернення: 08.12.2020). 14. Вплив пандемії на IT-індустрію Львова у IT Research 5.0. Львівський IT Кластер. 29.12.2020. URL: https://itukraine.org.ua/impact-of-the-pandemic-on-the-it-industry-of-lviv-in-itresearch-5.0.html. (дата звернення: 08.12.2020). 15. Капітальні інвестиції підприємств за видами економічної діяльності (2010-2019). URL: http://www.ukrstat.gov.ua/operativ/operativ2020/fin/pdp/pdp_ue/kip_ed_2010_2019 ue.xlsx. (дата звернення: 08.12.2020). 16. Використання інформаційнокомунікаційних технологій на підприємствах у 2018-2019 роках. URL: http://www.ukrstat.gov.ua/operativ/operativ2018/zv/ikt/viktp2018-2019_u.xls. (дата звернення: 08.12.2020). 17. Наявність у домогосподарствах окремих товарів тривалого користування 2010-2018. URL: 
Серія «Економічні науки»

Випуск 4(92) 2020 p.

http://www.ukrstat.gov.ua/operativ/operativ2007/gdvdg_rik/dvdg_u/Ndtt2010-.xls (дата звернення: 08.12.2020). 18. Доступ домогосподарств України до інтернету у 2019 році. Статистичний збірник. URL: http://www.ukrstat.gov.ua/druk/publicat/kat_u/2020/zb/07/zb__dd_in19.pdf. (дата звернення: 08.12.2020). 19.Дослідження цифрових навичок українців. міністерство цифрової трансформації України. 2019. URL: https://osvita.diia.gov.ua/uploads/0/585-

cifrova_gramotnist_naselenna_ukraini_2019_compressed.pdf. (дата звернення: 08.12.2020). 20. Кількість суб'єктів господарювання за видами економічної діяльності (2010-2019). URL: http://www.ukrstat.gov.ua/operativ/operativ2018/fin/pssg/pssg_u/ksg_ek_2010_201 9_ue.xlsx. (дата звернення: 08.12.2020). 21. Кількість суб'єктів великого, середнього, малого та мікропідприємництва за видами економічної діяльності (2010-2019).

URL: http://www.ukrstat.gov.ua/operativ/operativ2019/fin/pssg/ksg_vsmm_ek_2010_2019 _u.xlsx. (дата звернення: 08.12.2020). 22. Податковий кодекс України 02.12.2010 № 2755-УІ. Дата оновлення: 01.12.2020. URL: https://zakon.rada.gov.ua/laws/show/2755-17 (дата звернення: 10.12.2020). 23. Кількість зайнятих працівників у суб'єктів господарювання за видами економічної діяльності (2010-2019). URL: http://www.ukrstat.gov.ua/operativ/operativ2019/fin/pssg/kzpsg_ek_2010_2019_ue. xlsx (дата звернення: 08.12.2020). 24. Показники балансу підприємств за видами економічної діяльності з розподілом на великі, середні, малі та мікропідприємства (2013-2019).

URL: http://www.ukrstat.gov.ua/operativ/operativ2018/fin/fin_new/fin_new_u/pbp_ek_vs mm_2013_2019_ue.xlsx (дата звернення: 08.12.2020). 25. Рентабельність операційної та усієї діяльності підприємств за видами економічної діяльності 3 розподілом на великі, середні, малі та мікропідприємства (2010-2019). URL: http://www.ukrstat.gov.ua/operativ/operativ2018/fin/fin_new/fin_new_u/rodp_ek_vs mm_2010_2019_ue.xlsx (дата звернення: 08.12.2020).

\section{REFERENCES:}

1. Babanin 0. S. Statystyka rozvytku IT-rynku v SShA, Ukraini y sviti. Statystyka Ukrainy. 2013. № 1. S. 22-27. URL: http://nbuv.gov.ua/j-pdf/su_2013_1_6.pdf (data zvernennia: 08.12.2020). 2. Vynnychuk R. 0., Skliaruk T. V. Osoblyvosti rozvytku ITrynku v Ukraini: stan ta tendentsii. Visnyk Natsionalnoho universytetu «Lvivska politekhnika». Lohistyka. $2015 . \quad$ № 833. S. 3-8. URL: http://nbuv.gov.ua/UJRN/VNULPL_2015_833_3 (data zvernennia: 08.12.2020). 3. Hanushchak-Yefimenko L. M. Osoblyvosti rozvytku pidpryiemnytstva v IT-sferi Ukrainy. Aktualni problemy ekonomiky. 2016. №10. S. 55-67. URL: http://nbuv.gov.ua/UJRN/ape_2016_10_8 (data zvernennia: 08.12.2020). 4. Zhuravlov O. V., Simachov 0. A. Statystychne doslidzhennia rynku IT-posluh v Ukraini. Statystyka Ukrainy. $2018 . \quad$ № $4 . \quad$ S. 25-33. URL: https://sujournal.com.ua/index.php/journal/article/view/207/183 (data zvernennia: 08.12.2020). 5. Sardak S. E., Stavitska A. V. Doslidjennya strukturi i tendentsiy rozvitku svitovogo rinku informatsiynih tehnologiy. Tehnologicheskiy audit $i$ rezervyi proizvodstva. № 4/5(24). $2015 . \quad$ S. 96-100. URL: http://nbuv.gov.ua/UJRN/Tatrv_2015_4\%285\%29_21 (data zvernennia: 08.12.2020). 6. Rozvytok ukrainskoi IT-industrii. Analitychnyi zvit. Kyiv, zhovten 2018. 68 s. URL: 
https://ko.com.ua/files/u125/ukrainian_it_industry_report_ukr.pdf (data zvernennia: 08.12.2020). 7. Volianiuk I. Osoblyvosti bukhobliku v IT-kompaniiakh. Visnyk. Ofitsiino pro podatky. №12 (916) vid 24.03.2017 r. URL: http://www.visnuk.com.ua/uk/publication/100004441-osoblivosti-bukhobliku-v-itkompaniyakh?issue=5583 (data zvernennia: 08.12.2020). 8. Osnovna nomenklatura produktsii (ONP). URL: http://www.ukrstat.gov.ua/klasf/st_kls/onp_2020.pdf (data zvernennia: 16.03.2020). 9. Klasyfikatsiia zovnishnoekonomichnykh posluh. URL: http://www.ukrstat.gov.ua/klasf/st_kls/kzep_xls.rar (data zvernennia: 08.12.2020). 10. Klasyfikatsiia vydiv ekonomichnoi diialnosti (KVED-2010). URL: http://www.ukrstat.gov.ua/klasf/nac_kls/dc_009_xls.rar. (data zvernennia: 08.12.2020). 11. Obsiah realizovanoi produktsii (tovariv, posluh) subiektiv hospodariuvannia za vydamy ekonomichnoi diialnosti (2010-2019). URL: http://www.ukrstat.gov.ua/operativ/operativ2018/fin/pssg/pssg_u/orpsg_ek_2010_2 019_ue.xlsx. (data zvernennia: 08.12.2020). 12. Dynamika zovnishnoi torhivli posluhamy za vydamy (2008-2019). URL: http://www.ukrstat.gov.ua/operativ/operativ2008/zd/dseip/ dseip2007_u.xls. (data zvernennia: 08.12.2020). 13. Valovyi vnutrishnii produkt (1990-2019). URL: http://www.ukrstat.gov.ua/operativ/operativ2020/vvp/vvp_rik/vvp_rik90-19.xlsx.

(data zvernennia: 08.12.2020). 14. Vplyv pandemii na IT-industriiu Lvova u IT Research 5.0. Lvivskyi IT Klaster. 29.12.2020. URL: https://itukraine.org.ua/impact-of-thepandemic-on-the-it-industry-of-lviv-in-it-research-5.0.html. (data zvernennia: 08.12.2020). 15. Kapitalni investytsii pidpryiemstv za vydamy ekonomichnoi diialnosti (2010-2019).

URL: http://www.ukrstat.gov.ua/operativ/operativ2020/fin/pdp/pdp_ue/kip_ed_2010_2019 ue.xlsx. (data zvernennia: 08.12.2020). 16. Vykorystannia informatsiinokomunikatsiinykh tekhnolohii na pidpryiemstvakh u 2018-2019 rokakh. URL: http://www.ukrstat.gov.ua/operativ/operativ2018/zv/ikt/viktp2018-2019_u.xls. (data zvernennia: 08.12.2020). 17. Naiavnist u domohospodarstvakh okremykh tovariv tryvaloho korystuvannia 2010-2018. URL: http://www.ukrstat.gov.ua/operativ/operativ2007/gdvdg_rik/dvdg_u/Ndtt2010-.xls (data zvernennia: 08.12.2020). 18. Dostup domohospodarstv Ukrainy do internetu u 2019 rotsi. Statystychnyi zbirnyk. URL: http://www.ukrstat.gov.ua/druk/publicat/kat_u/2020/zb/07/zb__dd_in19.pdf. (data zvernennia: 08.12.2020). 19. Doslidzhennia tsyfrovykh navychok ukraintsiv. Ministerstvo tsyfrovoi transformatsii Ukrainy. 2019. URL: https://osvita.diia.gov.ua/uploads/0/585-

cifrova_gramotnist_naselenna_ukraini_2019_compressed.pdf (data zvernennia: 08.12.2020). 20. Kilkist subiektiv hospodariuvannia za vydamy ekonomichnoi diialnosti (2010-2019).

URL: http://www.ukrstat.gov.ua/operativ/operativ2018/fin/pssg/pssg_u/ksg_ek_2010_201 9_ue.xlsx. (data zvernennia: 08.12.2020). 21. Kilkist subiektiv velykoho, serednoho, maloho ta mikropidpryiemnytstva za vydamy ekonomichnoi diialnosti (2010-2019). URL:

http://www.ukrstat.gov.ua/operativ/operativ2019/fin/pssg/ksg_vsmm_ek_2010_2019 _u.xlsx. (data zvernennia: 08.12.2020). 22. Podatkovyi kodeks Ukrainy 02.12.2010 № 2755-Ul. Data onovlennia: 01.12.2020. URL: https://zakon.rada.gov.ua/laws/show/2755-17 (data zvernennia: 10.12.2020). 23. Kilkist zainiatykh pratsivnykiv u subiektiv hospodariuvannia za vydamy ekonomichnoi diialnosti (2010-2019). URL: http://www.ukrstat.gov.ua/operativ/operativ2019/fin/pssg/kzpsg_ek_2010_2019_ue. 
xlsx (data zvernennia: 08.12.2020). 24. Pokaznyky balansu pidpryiemstv za vydamy ekonomichnoi diialnosti $z$ rozpodilom na velyki, seredni, mali ta mikropidpryiemstva (2013-2019).

http://www.ukrstat.gov.ua/operativ/operativ2018/fin/fin_new/fin_new_u/pbp_ek_vs mm_2013_2019_ue.xlsx (data zvernennia: 08.12.2020). 25. Rentabelnist operatsiinoi ta usiiei diialnosti pidpryiemstv za vydamy ekonomichnoi diialnosti z rozpodilom na velyki, seredni, mali ta mikropidpryiemstva (2010-2019). URL: http://www.ukrstat.gov.ua/operativ/operativ2018/fin/fin_new/fin_new_u/rodp_ek_vs mm_2010_2019_ue.xlsx (data zvernennia: 08.12.2020).

Roshchyk I. A. [1; ORCID ID: 0000-0002-3155-2727], Candidate of Economics (Ph.D.), Associate Professor,

Ovsiichuk O. S. [1; ORCID ID: 0000-0001-7925-8378] Senior Student

${ }^{1}$ National University of Water and Environmental Engineering, Rivne

\section{IT PRODUCTS MARKET: ANALYSIS FOR BUSINESS ESTABLISHMENT AND DEVELOPMENT}

According to the method proposed in the paper, the market capacity of IT products for the period 2010-2018 in Ukraine is estimated. Using statistical methods of time series analysis the development of the IT products market is analyzed. It has grown 15 times over the past 10 years, while exports have grown 26 times.

The main IT product sold in Ukraine is computer programming services. Based on the correlation-regression analysis, a model of the IT products market capacity and GDP per capita dependence of Ukraine is made. Based on it, it is projected that the market capacity ranged from 120 to 178 billion UAH due to the fall of the Ukrainian economy in 2020.

After structural and dynamic analysis it was found that the main activities which buy software, have their own website, buy cloud computing services, order analysis of «big data» are ICT, trade, processing industry. The biggest reserves for the expansion of IT business should be sought in the areas of transport, construction and real estate.

It is determined that during the analyzed period the competition in the market of IT products intensified, as the number of their manufacturers increased more than 5 times. These are mainly natural entitiesentrepreneurs who enjoy tax benefits in the form of a simplified taxation system. The number of employees in the IT business has increased more than 3 times during this period.

For assessing the investment needs in the IT sector, a workplace cost indicator is proposed. Using the ratio of labor productivity and the workplace cost, it was found that investments in the IT sector pay off almost twice as 
fast as in enterprises of other activities. This is confirmed after the profitability analysis of different types of IT business - it is mostly positive and is at the average level in the economy of Ukraine.

Keywords: Information Technology; IT products market; market capacity; forecasting; the workplace cost.

Рощик И. А. ${ }^{[1 ;}$ ORCID ID: 0000-0002-3155-2727], к.э.Н., доцент,

Овсийчук Е. С. ${ }^{[1 ;}$ ORCID ID: 0000-0001-7925-8378], соискатель высшего образования первого (бакалаврского) уровня

${ }^{1}$ Национальный университет водного хозяйства и природопользования, г. Ровно

\section{РЫНОК ИТ-ПРОДУКТОВ: АНАЛИТИКА ДЛЯ СОЗДАНИЯ И РАЗВИТИЯ БИЗНЕСА}

Обоснованы теоретико-методические основы анализа рынка ИТпродуктов для принятия решений о создании и развитии бизнеса. Уточнено место ИТ-продуктов и ИТ-сферы в статистических классификациях. По предложенной в работе методике оценены емкость рынка ИТ-продуктов за период 2010-2018 годов в Украине и проанализировано его развитие с использованием статистических методов анализа рядов динамики. На основе корреляционнорегрессионного анализа составлена модель зависимости емкости рынка ИТ-продуктов от ВВП на душу населения Украины, которая может быть использована для прогнозирования. Выявлены основные отраслевые характеристики покупателей ИТ-продуктов и оценены резервы наращивания потребления и объемов рынка. Определены основные характеристики производителей ИТ-продуктов. По предложенному в работе показателю стоимости рабочего места оценены инвестиционные потребности В ИТ-сфере. С использованием соотношения производительности труда и стоимости рабочего места, рентабельности операционной деятельности проанализирована эффективность ИТпредпринимательства в Украине.

Ключевые слова: информационные технологии; рынок ИТ-продуктов; емкость рынка; прогнозирование, стоимость рабочего места. 